\title{
Wojciech Sokół
}

ORCID ID: https://orcid.org/0000-0002-3905-0852

Uniwersytet Marii Curie-Skłodowskiej w Lublinie

\section{Kierunki i efekty polityczne zmian w systemach politycznych Polski i Ukrainy}

\section{Wprowadzenie}

W literaturze naukowej oraz w publicystyce powstało wiele opracowań na temat ewolucji systemów politycznych w Polsce i na Ukrainie, jak również analiz dotyczących poszczególnych instytucji ustrojowych, zmian w sferze społeczno-ekonomicznej oraz kulturowej w tych państwach. Niewiele jest natomiast prób porównywania obydwu systemów politycznych. Takie porównania wydają się zasadne, ponieważ pomimo podobnego punktu wyjścia efekty transformacji czy konsolidacji demokracji w porównywanych państwach okazują się zróżnicowane ${ }^{1}$. Ilustracją tego zjawiska może być chociażby badanie The Economist Intelligence Unit, w świetle którego Polska wprawdzie nie jest postrzegana jako tzw. pełna demokracja, to jednak w rankingu tym jej ocena w zakresie postępów demokratyzacji jest wyższa niż Ukrainy².

1 Wynikający z tradycyjnych teorii tranzytologii tzw. teleologizm transformacyjny (droga od autorytaryzmu do skonsolidowanej demokracji) w świetle wyników transformacji ustrojowej państw postradzieckich często jest kwestionowany. Zob. szerzej: T. Carothers, The End of the Transition Paradigm, „Journal of Democracy” 2002, nr 13, s. 5-21.

2 Za pełne demokracje uważa się państwa, które uzyskały od 8 do 10 punktów, do demokracji wadliwych zalicza się te z punktacją od 6 do 7,9, systemy hybrydowe obejmują państwa, które zdobyły od 4 do 5,9 punktów, zaś miano państw o reżimie autorytarnym noszą te z liczbą punktów poniżej 4 . A Report from the Economist Intelligence Unit, http://www.eiu.com/home.aspx\#offer-ss-data [dostęp: 27.05.2017]. Podobnie był oceniany poziom demokratyzacji na Ukrainie od lat 90 . XX wieku do 2006 roku. Według Nations in Transit były to oceny od 4,92 do 4,21 sytuujące Ukrainę wśród reżimów hybrydowych. W tym samym czasie Polska była oceniana jako demokracja skonsolidowana. Nations in Transit 2006, http: www.freedomhouse.hu/index.php?option=com_content\&task=view\&id=47 [dostęp: 16.04.2018]. 
Tabela 1. Analiza funkcjonalna polskiej i ukraińskiej demokracji w latach 2006-2017

\begin{tabular}{|l|c|c|c|c|c|c|c|c|c|c|}
\hline Rok & 2006 & 2008 & 2010 & 2011 & 2012 & 2013 & 2014 & 2015 & 2016 & 2017 \\
\hline $\begin{array}{l}\text { Wskaźnik poziomu } \\
\text { demokracji w Polsce }\end{array}$ & 7,30 & 7,30 & 7,05 & 7,12 & 7,12 & 7,12 & 7,47 & 7,09 & 6,83 & 6,67 \\
\hline $\begin{array}{l}\text { Wskaźnik poziomu } \\
\text { demokracji na Ukrainie }\end{array}$ & 6,94 & 6,94 & 6,30 & 5,94 & 5,91 & 5,84 & 5,42 & 5,70 & 5,70 & 5,69 \\
\hline
\end{tabular}

Źródło: The Economist Intelligence Unit’s Democracy Index - infografika [dostęp: 15.04.2018].

Warto zatem zwrócić uwagę na rozwiązania instytucjonalne w systemach politycznych Polski i Ukrainy oraz ich konsekwencje polityczne. W związku z tym w poniższym tekście zostanie podjęta próba odpowiedzi m.in. na takie pytania badawcze, jak: 1) jakie były podstawy konstytucyjne systemów politycznych Polski i Ukrainy?; 2) jakie funkcjonowały systemy rządów?; 3) jaka była specyfika mechanizmów rywalizacji politycznej oraz jej głównych aktorów, czyli partii politycznych?. Zakres czasowy opracowania obejmuje okres od rozpoczęcia przemian ustrojowych w Polsce (1989 r.) i początków niepodległości Ukrainy (1991 r.) do czasów współczesnych. W poniższej analizie wykorzystano zarówno metodę komparatystyczną, jak i analizę systemową oraz metodę instytucjonalną. Zasadniczym celem opracowania jest uzasadnienie tezy, że polski system polityczny na tle ukraińskiego charakteryzował się większą stabilnością i efektywnością, chociaż proces demokratyzacji trwa i nie zakończył się jeszcze pełną konsolidacją. Z kolei ukraińskie rozwiązania instytucjonalne nie pozwoliły na osiągnięcie podobnych jak w Polsce efektów politycznych.

\section{Konstytucyjny wymiar systemu politycznego w Polsce i na Ukrainie}

Analizując genezę i ewolucję obecnego polskiego i ukraińskiego systemu politycznego, należy zwrócić uwagę na uwarunkowania i sekwencję najważniejszych zmian ustrojowych w tych państwach.

Narastający w latach 80 . XX wieku kryzys społeczno-polityczny w istotnym stopniu podważył legitymację systemu politycznego Polskiej Rzeczypospolitej Ludowej, także $\mathrm{w}$ opinii większości dotychczasowych elit rządzących związanych z partią komunistyczną. W tej sytuacji w konsekwencji sekwencji wydarzeń, które następowały pod koniec lat 80 . XX wieku, zmianie uległ system polityczny ${ }^{3}$. Do tej pory w różnych środowiskach politycznych w Polsce oraz wśród historyków trwają spory i tworzone są określone narracje polityczne na temat tego, czy w Polsce miał miejsce upadek komunizmu, jego obalenie czy też był to demontaż kontrolowany przez związane z nim elity. Trudno również wskazać jednoznaczną datę zapoczątkowującą okres niepodległości.

3 Były to kolejno: kryzys gospodarczy, fala strajków z 1988 r., rozmowy „Okrągłego Stołu” z udziałem strony koalicyjno-rządowej oraz przedstawicieli części środowisk opozycyjnych popieranych jednak wówczas przez szerokie kręgi społeczeństwa, nowelizacja konstytucji PRL przyjętej 7 kwietnia oraz 29 grudnia 1989 r., kontraktowe wybory z 4 czerwca, zmiany w konfiguracji rządu w sierpniu 1989 r. Zob. szerzej: A. Dudek, Historia polityczna Polski 1989-2015, Kraków 2016, s. 17-140. 
W świetle niektórych opinii było to 4 czerwca (data kontraktowych, parlamentarnych wyborów), według innych moment zmian konstytucyjnych, jeszcze inni za szczególnie symboliczne wydarzenie uznają przekazanie insygniów prezydenta II Rzeczypospolitej nowo wybranemu prezydentowi.

Już w okresie tzw. Sejmu kontraktowego pojawiła się idea uchwalenia nowej konstytucji (w związku z 200. rocznicą Konstytucji 3 maja 1791). Efektem tego był m.in. projekt konstytucji przygotowany w Senacie 4 . Wysoki poziom fragmentaryzacji politycznej w Sejmie I kadencji wbrew oczekiwaniom społecznym utrudniał uchwalenie nowej konstytucji. W tej sytuacji za konieczne uznano uchwalenie aktu przejściowego, regulującego najważniejsze kwestie z zakresu wzajemnych relacji podstawowych organów władzy w państwie. W związku z tym 17 października 1992 r. Sejm uchwalił ustawę konstytucyjną „O wzajemnych stosunkach między władzą ustawodawczą i wykonawczą Rzeczypospolitej Polskiej oraz o samorządzie terytorialnym”, zwaną Małą Konstytucją. Ostatecznie proces transformacji ustrojowej zakończyło 2 kwietnia 1997 r. przyjęcie przez Zgromadzenie Narodowe (po prawie pięciu latach prac) Konstytucji Rzeczypospolitej Polskiej, zaaprobowanej przez społeczeństwo w drodze referendum przeprowadzonego 25 maja 1997 roku. Konstytucja ta weszła w życie i stała się najwyższym prawem w państwie 17 października 1997 roku$^{5}$. Konstytucja z 1997 r. będąca efektem kompromisu pomiędzy postkomunistycznym Sojuszem Lewicy Demokratycznej a postsolidarnościową, liberalną Unią Wolności zakłada m.in. dwuczłonową władzę wykonawczą. Krytycy silnego dualizmu egzekutywy w III RP wskazują na dysfunkcjonalny charakter tego rozwiązania ${ }^{6}$.

Po zwycięskich dla Prawa i Sprawiedliwości wyborach parlamentarnych i prezydenckich z 2015 roku podniesiono problem nieadekwatności do współczesnych uwarunkowań dotychczasowych regulacji konstytucyjnych i tym samym zmiany ustawy zasadniczej. Niezależnie od problemów z realizacją wymagań proceduralnych i zgromadzeniem poparcia tzw. większości konstytucyjnej, relewantne podmioty polityczne w Polsce są zgodne w kwestii, że potrzebne będą rozwiązania obowiązujące przez co najmniej kilka następnych dekad. W związku z tym od 2016 r. jest prowadzona na ten temat debata publiczna ${ }^{7}$. Według projektu Prawa i Sprawiedliwości konstytucja

4 A. Grześkowiak, Ustrój polityczny III Rzeczypospolitej według projektu konstytucji senackiej komisji konstytucyjnej, „Roczniki Nauk Prawnych”, Toruń 1991-1992, s. 99-106.

5 Dotychczas konstytucja RP była nowelizowana zaledwie dwukrotnie (art. 55, 99). Zob. szerzej: R. Stawicki, Zmiany Konstytucji Rzeczypospolitej Polskiej w latach 1997-2011 w świetle projektów ustaw oraz uchwalonych nowelizacji, Warszawa 2011, passim.

6 J. Szymanek, Zabezpieczenia konstytucji przed zmianą konstytucji, „Prawo i Polityka” 2015, nr 6, s. 15.

7 Ośrodek prezydencki opowiada się za wzmocnieniem kompetencji prezydenta. Z kolei w świetle prezentowanej 16 kwietnia 2018 r. tzw. ankiety konstytucyjnej większość ekspertów, podobnie jak większość parlamentarna po 2015 r., opowiedziała się za ustanowieniem jednego ośrodka władzy wykonawczej w postaci rządu i stojącego na jego czele premiera. To oznaczałoby, że kompetencje prezydenta zostałyby uszczuplone i tym samym system rządów upodobniłby się do modelu kanclerskiego. Będzie spór między Andrzejem Dudą a PiS. Partia chce ograniczenia kompetencji 
powinna spełniać dziesięć warunków: pełnić role państwowotwórczą oraz narodowotwórczą, jasno określać wartości moralne i tradycje narodowe tworzące aksjologiczny fundament państwa, zawierać Invocatio Dei, budować tożsamość antykomunistyczną przez odwołanie do tradycji niepodległościowej i demokratycznej, czynić najwyższym prawem zasadę, że racją istnienia i działania państwa jest dobro wspólne obywateli, podkreślać znaczenie rodziny jako podstawowej instytucji życia społecznego oraz wskazywać, że jej uprawnienia są pod szczególną opieką państwa, zapewniać nadrzędność polskiego prawa konstytucyjnego nad prawem międzynarodowym, precyzować usytuowanie poszczególnych władz, zwłaszcza ośrodków władzy wykonawczej, jasno określać podział kompetencji administracyjnych, wyrażać klarownie koncepcję kontroli państwowej, stojącej na straży majątku publicznego ${ }^{8}$.

Powstanie niepodległej Ukrainy było polityczną konsekwencją zmian w Związku Radzieckim i postępującej erozji systemu politycznego tego państwa. Okres pierestrojki to czas aktywizacji ugrupowań demokratycznych, w tym również w dość ograniczonym stopniu na terytorium ukraińskim ${ }^{9}$. W efekcie postępującej dezintegracji ZSRR, Rada Najwyższa Ukraińskiej SRR (której przewodniczącym był późniejszy prezydent Leonid Krawczuk) 16 lipca 1990 roku uchwaliła deklarację o suwerenności republiki, $\mathrm{z}$ zastrzeżeniem pozostawania państwa $\mathrm{w}$ ramach ZSRR. Po nieudanym zamachu stanu w Moskwie (tzw. puczu Janajewa z 19 sierpnia 1991) Rada Najwyższa Ukrainy proklamowała 24 sierpnia 1991 roku Akt Niepodległości Ukrainy i odpowiednie ustawy towarzyszące tej deklaracji. Kilka miesięcy później, 1 grudnia 1991 w powszechnym referendum, połączonym $\mathrm{z}$ wyborami prezydenckimi zatwierdzono deklarację niepodległości. Pierwszym państwem, które uznało niepodległość Ukrainy na arenie międzynarodowej, była Polska ${ }^{10}$. Zatem wpływ na niepodległość Ukrainy miały zarówno wydarzenia zewnętrzne, jak i wola elit ukraińskich uzyskania własnej państwowości.

Przez kilka następnych lat obowiązywały na Ukrainie znowelizowane przepisy konstytucji byłej Ukraińskiej Socjalistycznej Republiki Radzieckiej. Dopiero w październiku 1995 roku powołano Komisję Konstytucyjną, która w marcu 1996 zakończyła prace i przedłożyła Radzie Najwyższej projekt nowej konstytucji ${ }^{11}$. Przeciw temu projektowi występowali komuniści, a także mieszkańcy i władze Krymu. Przedmiotem sporu pomiędzy prezydentem a lewicowymi deputowanymi były m.in. kwestie poprawek

prezydenta, http://wiadomosci.gazeta.pl/wiadomosci/7,114884,23278047,bedzie-spor-miedzyandrzejem-duda-a-pis-partia-chce-ograniczenia.html [dostęp: 16.04.2018].

8 Projekt Prawa i Sprawiedliwości. Konstytucja Rzeczypospolitej Polskiej, styczeń 2010, http:// niezniknelo.com/konstytucjaPiS [dostęp: 16.04.2018].

9 W. Baluk, Ksztattowanie systemu partyjnego Ukrainy w okresie transformacji ustrojowej (1987-2004), Wrocław 2006, s. 171-178.

10 Wynikało to z przekonania, że istnienie niepodległej Ukrainy czyni niemożliwym odbudowanie imperium rosyjskiego i znacznie osłabia niekorzystną dla Polski perspektywę współpracy niemiecko-rosyjskiej i było początkiem dobrych relacji polsko-ukraińskich. Zob. szerzej: J.M. Chodakiewicz, Międzymorze, Warszawa 2016, s. 254-255.

11 Zob. szerzej: E. Zieliński, System konstytucyjny Ukrainy, Warszawa 2007, s. 16-17. 
dotyczących języka państwowego, symboli narodowych i zasad własności. Prezydent Leonid Kuczma groził wówczas przeprowadzeniem referendum w sprawie konstytucji. Ostatecznie Rada Najwyższa 28 czerwca 1996 roku uchwaliła pierwszą konstytucję niepodległej Ukrainy, która weszła w życie z dniem jej uchwalenia ${ }^{12}$.

Przyjęta w 1996 roku konstytucja była więc efektem dość kruchego kompromisu. Już w roku 2000 pojawily się próby poważnej nowelizacji podjęte przez prezydenta L. Kuczmę. W okresie rewolucji pomarańczowej dokonano nowelizacji konstytucji na mocy Ustawy o wprowadzeniu zmian do Konstytucji Ukrainy z 8 grudnia 2004 roku. Zmiany dotyczyły ponownego podziału kompetencji pomiędzy poszczególnymi segmentami władzy oraz kolejny raz stanowiły kompromis pomiędzy wpływowymi grupami oligarchicznymi rywalizującymi o władzę. Dokonana nowelizacja była jednak niezgodna z przewidzianymi w tej ustawie zasadniczej procedurami (art. 157-159). Wprowadzone w 2004 roku rozwiązania, chociaż posiadały wątpliwą legitymizację proceduralną, zapobiegły jednak ewolucji systemu politycznego w kierunku autorytaryzmu, wzmocniły pluralizm polityczny, wolność mediów, osłabiły polityczną rolę prezydenta ${ }^{13}$.

W 2010 roku wykorzystując niedostateczną legitymację formalną dokonanej 6 lat wcześniej nowelizacji, w nowej już rzeczywistości politycznej pod rządami prezydenta Wiktora Janukowycza parlament zdominowany przez proprezydencką Partię Regionów dokonał powrotu do wcześniejszych regulacji ustrojowych. Sąd Konstytucyjny wydał orzeczenie w sprawie złamania procedury nowelizacji konstytucji w okresie rewolucji pomarańczowej i zarazem przywrócił poprzednie brzmienie ukraińskiej ustawy zasadniczej $^{14}$. Sąd Konstytucyjny na Ukrainie w kontekście regulacji konstytucyjnych dokonywanych w różnym czasie był albo pomijany, albo wykazywał się daleko posuniętą submisyjnością. Po 2010 roku prezydent odzyskał silną pozycję ustrojową w strukturze organów państwowych, co stało w sprzeczności z rozbudzonymi aspiracjami demokratycznymi znacznej części Ukraińców, jak również wzbudzało opór części oligarchów niezadowolonych z tego kierunku ewolucji ustrojowej.

Siła obozu prezydenta W. Janukowycza w konfrontacji ze słabą opozycją parlamentarną nie pozwoliła rozwiązać narastającego kryzysu politycznego metodami właściwymi dla demokratycznej alternacji władzy. Na przełomie 2013/2014 roku tzw. rewolucja Euromajdanu doprowadziła do obalenia dotychczasowego układu rządzącego. Wkrótce też miał miejsce powrót do mechanizmów ustrojowych z 2004 roku. W krótkim czasie Rada Najwyższa podjęła Ustawę o przywróceniu obowiązywania wybranych norm

12 Warto podkreślić, że Ukraina była ostatnim państwem postradzieckim, które dopiero 4,5 roku po rozpadzie ZSRR przyjęło konstytucję. Zob. szerzej: G. Kasjanow, Ukraina 1991-2007. Narisi nowimnoj istorii, Kiiw 2008, s. 62-63.

13 L. Hurska-Kowalczyk, Ewolucja form rządów na Ukrainie, [w:] Dylematy rozwoju Ukrainy, red. L. Hurska-Kowalczyk, Szczecin 2011, s. 35; K. Fedorowicz, „Pomarańczowa rewolucja” na Ukrainie - czas realizacji wyborczych deklaracji, [w:] „Pomarańczowa rewolucja” - szansa dla ukraińskiej transformacji politycznej, red. A. Furier, Szczecin 2006, s. 129-147.

14 A. Stelmach, Legalność zmiany władzy na Ukrainie, „Środkowoeuropejskie Studia Polityczne” 2015, vol. 4, s. 16-17. 
Konstytucji Ukrainy $(21.02 .2014)^{15}$. Tym razem również zmiany rangi konstytucyjnej dokonano bez przewidzianej w ustawie zasadniczej obowiązkowej konsultacji z Sądem Konstytucyjnym $^{16}$. Na początku czerwca 2016 roku Rada Najwyższa dokonała również zmiany konstytucji w kwestiach wymiaru sprawiedliwości ${ }^{17}$.

Dokonując periodyzacji rozwoju polskiego systemu politycznego, należy zauważyć, że w pierwszej fazie w latach 1989-1992 dokonywał się demontaż poprzedniego systemu i kształtowanie demokratycznych instytucji. Druga faza wiąże się z uchwaleniem „Małej Konstytucji", która formalnie wprowadziła do polskiego systemu politycznego trójpodział władz. Początek trzeciej fazy wiąże się z przyjęciem Konstytucji z 2 kwietnia $1997^{18}$. Kolejna faza może wiązać się ze zmianą rozwiązań rangi konstytucyjnej w konsekwencji debaty na ten temat rozpoczętej w 2016 roku. Generalnie widoczna jest stabilizacja w wymiarze konstytucyjnym. Na Ukrainie w odróżnieniu od państwa polskiego miała miejsce dość duża dynamika zmian konstytucyjnych. Po okresie przejściowym przyjęta w 1996 roku konstytucja była poważnie modyfikowana w 2004, 2010 i 2014 roku. Poszczególne środowiska polityczne, przejmujące $\mathrm{w}$ różnych okolicznościach władzę polityczną przeprowadzały zmiany instytucjonalne i traktowały je jako formułę legitymizacji swojej uprzywilejowanej pozycji ${ }^{19}$. Analizując wymiar konstytucyjny ukraińskiego systemu politycznego, należy zwrócić uwagę na dość instrumentalne traktowanie zmian ustawy zasadniczej zgodnie z preferencjami dominujących $\mathrm{w}$ danym momencie sił politycznych. Tego rodzaju praktyka, a szczególnie lekceważenie zasady legalizmu, dawało zawsze przesłanki do podważania prawomocności tych zmian w przyszłości i stanowiło zachętę dla podobnego postępowania przez kolejne układy rządzące.

\section{Wymiar systemów rządów}

W Polsce w okresie transformacji ustrojowej ustanowiono system rządów mieszczący się $\mathrm{w}$ ramach demokracji parlamentarnej. Występowały różnice $\mathrm{w}$ rozwiązaniach konstytucyjnych przyjętych w 1989, 1992 oraz 1997 roku, jednak mieścily się one w ramach parlamentarnego systemu rządów.

15 Zakon Ukrajiny pro widnowlennia diji okremych polożen' Konstytuciji Ukrajiny wid 21 II 2014, „Widomosti Werhownoi Radi” 2014, nr 11, poz. 143.

16 Konstytucja w art. 159 stanowi, że „Rada Najwyższa Ukrainy rozpatruje projekt ustawy o wprowadzeniu zmian do Konstytucji Ukrainy po podjęciu przez Sąd Konstytucyjny Ukrainy orzeczenia o zgodności projektu z wymogami artykułów 157 i 158 niniejszej Konstytucji”. Art. 157, Konstytucja Ukrainy, Warszawa, s. 86.

17 Zakon Ukrajiny pro zminy do Konstytuciji Ukrajiny (szczodo pravosuddia), http://zakon5.rada.gov. ua/laws/show/1401-VIII [dostęp: 16.04.2018].

18 Rozwiązania przyjęte w konstytucji z 1997 roku okazały się na tle innych państw Europy Środkowo-Wschodniej wyjątkowo trwałe. Zob. szerzej: A. Rakowska, K. Skotnicki, Konstytucja RP na tle innych obowiązujących Ustaw zasadniczych państw Europy Srodkowo-Wschodniej i Południowej, „Przegląd Sejmowy” 2007, nr 4, s. 215-216.

19 Zob. szerzej: K. Fedorowicz, Transformacja systemowa na Ukrainie - etap przejściowy czy nowy model państwa, [w:] Od totalitaryzmu do demokracji. Wybrane problemy okresu przemian, red. T. Wallas, Poznań 2003, s. 43-55. 
W 1989 roku reaktywowano, mającą tradycję sięgającą początków II Rzeczypospolitej, instytucję Prezydenta RP, którego legitymację wzmocniono wprowadzeniem w 1990 r. powszechnych i bezpośrednich wyborów. Restytucja instytucji prezydenta dokonana nowelą z dnia 7 kwietnia 1989 r. odzwierciedlała kompromis polityczny Okrągłego Stołu. Nie była ona przyporządkowana określonej wizji doktrynalnej czy też spójnej konstrukcji systemu rządów. W latach 1989-1997 koncepcja prezydentury była kształtowana zasadniczo pod wpływem praktyki konstytucyjnej, ściśle powiązanej z rozwojem sytuacji politycznej, w ramach której istniała względna równowaga pomiędzy obozem postsolidarnościowym a obozem postkomunistycznym i przekonanie podmiotów życia politycznego, że zasady, wartości i instytucje demokracji parlamentarnej są rozwiązaniem trwałym ${ }^{20}$.

Ostateczny kształt prawnoustrojowy instytucji Prezydenta RP został normatywnie uregulowany w obowiązującej Konstytucji z 2 kwietnia 1997 r. Pozycję Prezydenta RP w systemie ustrojowym państwa wyznaczają: zasada podziału władz, określone w art. 126 Konstytucji RP zadania ustrojowe oraz przyjęty model ustrojowy dualistycznej egzekutywy. Artykuł 10 ust. 2 Konstytucji RP stanowi, że „władzę wykonawczą sprawuje Prezydent Rzeczypospolitej i Rada Ministrów”. Konstytucja z 1997 r. przyjęła jednocześnie model nierównoprawnej dualistycznej egzekutywy. Przesądzają o tym modelu unormowania konstytucyjne dotyczące podziału zadań ustrojowych pomiędzy organami tworzącymi strukturę organizacyjną władzy wykonawczej.

Zgodnie z art. 146 ust. 1 i 3 konstytucji Rada Ministrów została powołana do prowadzenia polityki państwa i kierowania administracją rządową. Nie oznacza to jednak, że Prezydent RP został w pełni pozbawiony kompetencji w zakresie wykonywania władzy wykonawczej. Jego rola ustrojowa jako organu egzekutywy jest znacznie ograniczona w stosunku do Rady Ministrów, stanowi zarazem jeden z elementów kształtujących jego pozycję w systemie ustrojowym państwa ${ }^{21}$. Określone konstytucyjnie zadania wiążą się z ochroną podstawowych wartości dla państwa, którymi są: suwerenność, integralność terytorialna i bezpieczeństwo państwa. Konstytucja ustanawia zatem Prezydenta RP, obok innych organów państwa, nadzwyczajnym strażnikiem tych wartości oraz nakłada zadania ochrony ciągłości funkcjonowania państwa i jego konstytucyjnych władz w sytuacji zagrożenia bezpieczeństwa państwa ${ }^{22}$. Powierzenie Prezyden-

20 Zob. szerzej: Prezydent w Polsce po 1989 r. Studium politologiczne, red. R. Glajcar, M. Migalski, Warszawa 2006, passim.

21 Status prawnoustrojowy Prezydenta RP wyznaczają w szczególności jego zadania ustrojowe oraz system powszechnych i bezpośrednich wyborów przez naród. Konstytucja w art. 126 stanowi, że: 1) Prezydent Rzeczypospolitej jest najwyższym przedstawicielem Rzeczypospolitej Polskiej i gwarantem ciągłości władzy państwowej; 2) Prezydent Rzeczypospolitej czuwa nad przestrzeganiem Konstytucji, stoi na straży suwerenności i bezpieczeństwa państwa oraz nienaruszalności i niepodzielności jego terytorium. Konstytucja Rzeczypospolitej Polskiej, oprac. D. Dudek, Lublin 2007, s. 93.

22 W doktrynie prawa konstytucyjnego, na podstawie konstytucyjnie określonych zadań, Prezydentowi RP przypisuje się cztery zasadnicze funkcje ustrojowe w systemie polityczno-ustrojowym państwa: 1) funkcję klasycznej głowy państwa; 2) funkcję arbitra politycznego i gwaranta ciągłości władzy 
towi Rzeczypospolitej wykonywania powołanych funkcji jest powiązane ściśle ze sferą szczegółowych jego kompetencji, które zostały określone przepisami konstytucyjnymi oraz w około 140 ustawach.

Należy zauważyć, że w kolejnych regulacjach konstytucyjnych w Polsce miał miejsce proces ograniczania kompetencji prezydenta. I tak, w 1997 roku zrezygnowano z tzw. resortów prezydenckich, osłabiono siłę weta prezydenckiego oraz wprowadzając wymóg konstruktywnego wotum nieufności, ograniczono możliwości rozwiązania parlamentu. Posiadając mandat otrzymany bezpośrednio od narodu, Prezydent RP został wyposażony w kompetencje mieszczące się w ramach systemu demokracji parlamentarnej. W efekcie w relacjach pomiędzy konstytucyjnymi organami władzy dochodziło niekiedy do rywalizacji, konfliktów i sporów kompetencyjnych. Relacje pomiędzy głową państwa a rządem były w istotnym stopniu uzależnione od stopnia homogeniczności władzy wykonawczej. Najczęściej prezydent wywodził się z opcji politycznej tworzącej rząd popierany przez większość parlamentarną. Niekiedy reprezentował orientację opozycyjną wobec Rady Ministrów (tzw. kohabitacja). W okresie kohabitacji (lata 1993-1995; 1997-2001; 2007-2010) niejednokrotnie dochodziło do konfliktów pomiędzy sprawującymi urząd prezydenta a rządami i większością parlamentarną. Niezależnie od mechanizmów instytucjonalnych na powyższe relacje wpływał m.in. styl przywództwa prezydenckiego czy przywództwa premierowskiego oraz bardziej lub mniej aktywna, konfrontacyjna lub koncyliacyjna rola tych podmiotów. W przypadku aktywnej (konfrontacyjnej) prezydentury niejednokrotnie miały miejsce napięcia w relacjach pomiędzy najważniejszymi instytucjami systemu politycznego. Przejawem konfliktów było stosowanie przez głowę państwa weta w procesie legislacyjnym, spory kompetencyjne w kwestiach polityki zagranicznej, roli prezydenta w zakresie zwierzchnictwa nad siłami zbrojnymi i jego decyzji wobec sądów i trybunałów. Zatem, chociaż nie brakowało także głosów postulujących odejście od dotychczasowych mechanizmów na rzecz prezydencjalizmu, semiprezydencjalizmu lub modelu kanclerskiego, rozwiązania prawne, jak również praktyka polityczna w Polsce w zakresie systemów rządów od ponad ćwierćwiecza mieściły się w ramach zmodyfikowanego systemu parlamentarno-gabinetowego.

Na Ukrainie w podobnym okresie występowała zmienność w zakresie systemów rządó ${ }^{23}$. Na progu niepodległości, w ślad za podobnymi rozwiązaniami w innych republikach radzieckich także na Ukrainie ustanowiono nieznaną wcześniej w tym kraju instytucję prezydenta ${ }^{24}$. Pierwszym prezydentem wybrano Leonida Krawczuka (jeden

państwowej; 3) funkcję władzy rezerwowej na wypadek zagrożenia bezpieczeństwa państwa; 4) funkcję organu egzekutywy. Zob. m.in.: R. Mojak, Pozycja ustrojowa Prezydenta RP w świetle nowej Konstytucji RP, „Państwo i Prawo” 1997, nr 11-12, s. 54-70.

23 Zob. szerzej: K. Fedorowicz, Transformacja systemowa na Ukrainie - etap przejściowy czy nowy model państwa, [w:] Od totalitaryzmu do demokracji. Wybrane problemy okresu przemian, red. T. Wallas, Poznań 2003, s. 43-56.

24 Zob. szerzej: A. Olechno, Instytucja Prezydenta w systemie konstytucyjnych organów Ukrainy (19962005), Toruń 2009, passim. 
z byłych liderów Komunistycznej Partii Ukrainy). Głowa państwa stała na czele władzy wykonawczej, a także przejęła wiele funkcji od Rady Najwyższej, gdyż przestała ona być najwyższym organem władzy państwowej, a stała się jedynym organem władzy ustawodawczej. W roku 1994 odbyły się przedterminowe wybory prezydenckie, w których zwyciężył Leonid Kuczma, który starał się wzmocnić pozycję prezydenta zarówno wobec parlamentu, jak i wobec rządu. Podjął także próbę stworzenia administracji państwowej podległej głowie państwa i niezależnej od rad terenowych.

W tamtym okresie trwały również ogólnonarodowe dyskusje nad projektem nowej konstytucji. Przedstawiony w 1992 roku prezydencki projekt autorstwa L. Krawczuka wywołał krytykę ze względu na przyznanie w nim zbyt szerokiego katalogu uprawnień głowie państwa, co w efekcie doprowadziłoby do powstania systemu prezydenckiego. Podobnie jak poprzedni prezydent, tak i L. Kuczma optował za silną władzą prezydencką, jednakże sprzeciwiali się temu deputowani lewicowi, obawiający się naruszenia równowagi społeczno-politycznej w państwie na rzecz ośrodka, z którym powiązany byłby prezydent. 7 czerwca 1995 roku zawarto porozumienie pomiędzy parlamentem a prezydentem, które regulowało zasady organizacji i funkcjonowania władzy państwowej i samorządu terytorialnego do czasu uchwalenia nowej konstytucji. W konsekwencji przyjęcia Konstytucji z 28 czerwca 1996 roku utrwalił się system rządów określany najczęściej jako prezydencko-parlamentarny, który funkcjonował przez 8 kolejnych lat. $\mathrm{W}$ ramach wykreowanego w latach 90 . XX wieku systemu rządów zaznaczyła się aktywna rola prezydenta L. Kuczmy, który m.in. dość często stosował weto ustawodawcze (np. ustawa o Gabinecie Ministrów była zawetowana osiem razy, ustawa wyborcza z 2001 r. pięciokrotnie) ${ }^{25}$.

W latach 2004-2010 funkcjonował system rządów nazywany parlamentarno-prezydenckim. Nastąpiło ograniczenie kompetencji głowy państwa z pozostawieniem mu istotnych prerogatyw w zakresie kreowania rządu. Do tzw. resortów prezydenckich należało Ministerstwo Spraw Zagranicznych, Ministerstwo Obrony Narodowej. W rezultacie nowelizacji Konstytucji z 2004 r. nastąpiło natomiast wzmocnienie pozycji rządu i premiera kosztem uprawnień prezydenta ${ }^{26}$. Również Rada Najwyższa Ukrainy uwolniła się od dominacji prezydenta. W większym zakresie sprawowała kontrolę nad Gabinetem Ministrów. Zgodnie z założeniami systemu demokracji parlamentarnej główna rola w tworzeniu rządu przypadła większościowym frakcjom (koalicjom) deputowanych. Nowelizacja wprowadzała mechanizmy tworzenia tzw. party government („rządu partyjnego"). Deputowanych zobligowano do członkostwa we frakcjach partyjnych, natomiast koalicja rządowa składająca się z ugrupowań parlamentarnych, które dysponują bezwzględną większością w Radzie Najwyższej, musiała powstać w ciągu miesiąca od ukonstytuowania się nowo wybranej Rady Najwyższej lub od upadku poprzedniego Gabinetu Ministrów, pod rygorem możliwości rozwiązania parlamentu przez prezy-

25 L. Hurska-Kowalczyk, op. cit., s. 27.

26 T.A. Olszański, Sąd Konstytucyjny przywraca system prezydencki na Ukrainie, Ośrodek Studiów Wschodnich 2010, http://www.osw.waw.pl, s. 2 [dostęp: 27.09.2017]. 
denta. Powyższe regulacje nie zapobiegły coraz liczniejszym konfliktom w trójkącie parlament-prezydent-rząd i postępującej dezintegracji zwycięzców pomarańczowej rewolucji ${ }^{27}$.

W roku 2010 w konsekwencji zmiany układu rządzącego, wraz z zakwestionowaniem zmian konstytucyjnych $\mathrm{z}$ okresu pomarańczowej rewolucji nastąpił powrót do systemu prezydencko-parlamentarnego. Siły polityczne (głównie Partia Regionów), które dysponowały wówczas przewagą w Radzie Najwyższej, postanowiły porzucić bliższe demokracji parlamentarnej mechanizmy rządzenia. Stąd koncepcja powrotu do wcześniejszej wersji konstytucji, która dawała znacznie szersze uprawnienia prezydentowi $^{28}$. Z kolei nowelizacja lutowa z 2014 roku przywróciła system rządów ustanowiony 10 lat wcześniej. Tym samym po raz drugi na Ukrainie ustanowiono reguły gry bliższe systemowi rządów parlamentarno-prezydenckich ${ }^{29}$.

Reasumując, należy zauważyć, że w porównaniu z polskim systemem politycznym permanentnie opartym na mechanizmach demokracji parlamentarnej w państwie ukraińskim, w zależności od układu sił politycznych w poszczególnych okresach funkcjonowały co najmniej dwa różne systemy rządów. Wprowadzane mechanizmy relacji pomiędzy głównymi organami władzy pozwalają je sytuować pomiędzy prezydencjalizmem a parlamentaryzmem.

\section{Wymiar rywalizacji politycznej}

W końcowym okresie formalnego istnienia Polski Ludowej mechanizm alternacji władzy był konsekwencją kompromisu politycznego (formuła rozmów Okrągłego Stołu). Wybrany 4 czerwca 1989 roku tzw. Sejm kontraktowy, chociaż ilościowo zdominowany przez posłów związanych $\mathrm{z}$ dotychczasowym układem rządzącym, podjął działania na rzecz demokratyzacji systemu politycznego, m.in. uchwalając 28 czerwca 1991 r. ordynację wyborczą do obydwu izb parlamentu. Począwszy od elekcji z 27 października 1991 r., wszystkie wybory (zarówno prezydenckie, do Sejmu, Senatu, jak i wybory samorządowe) były już całkowicie wolne. Wyłaniane w konsekwencji elekcji sejmowych rządy koalicyjne były efektem układu sił w parlamencie. Powstawały rządy klasyfikowane jako koalicje minimalnie zwycięskie, jak również koalicje mniejszościowe ${ }^{30}$. Do 2011 roku wyniki wyborów każdorazowo kreowały nowy układ rządzący (tzw. wybory kratyczne).

27 Ł. Donaj, Współczesny kryzys społeczno-polityczny na Ukrainie jako przykład cykliczności (chroniczności?) procesów politycznych, „Środkowoeuropejskie Studia Polityczne” 2012, nr 3, s. 204-206.

28 T.A. Olszański, op. cit., s. 4.

29 Zob. szerzej: K. Fedorowicz, Ukraińskie rewolucje a parlamentaryzm, „Rocznik Instytutu Europy Środkowo-Wschodniej" 2014, z. 2, s. 57-74.

30 Zob. szerzej: W. Sokół, Partie na arenie parlamentarnej i gabinetowej, [w:] Współczesne partie i systemy partyjne. Zagadnienia teorii i praktyki politycznej, red. W. Sokół, M. Żmigrodzki, Lublin 2003, s. 182-197. 
Począwszy od 1991 roku, kluczowe dla systemu rządów parlamentarnych wybory do Sejmu są przeprowadzane na podstawie proporcjonalnego systemu wyborczego. W ramach formuły proporcjonalnej zmieniały się jednak rozwiązania szczegółowe, zwłaszcza w pierwszej dekadzie transformacji ${ }^{31}$. Przed kolejnymi wyborami sejmowymi, w latach 1993-2002 zmieniano rozmiary okręgów wyborczych, poziomy repartycji mandatów, metody transformacji głosów na mandaty (wykorzystywano zarówno metodę Hare'a-Niemeyera, zmodyfikowaną metodę Sainte-Laguë, jak i metodę d'Hondta), progi wyborcze, lecz formuła proporcjonalna od 1991 jest stałym elementem infrastruktury wyborczej (9 kolejnych elekcji) w Polsce. Systemy proporcjonalne do Sejmu oscylowały pomiędzy rozwiązaniami dającymi bardziej lub mniej proporcjonalny podział mandatów dla poszczególnych komitetów wyborczych. Na początku obecnego wieku nastąpiła ostatnia poważniejsza zmiana w ramach formuły wyborczej. Z kolei w 2011 roku wprowadzono kodyfikację prawa wyborczego, w konsekwencji której w ramach systemu większościowego do Senatu ustanowiono okręgi jednomandatowe. Stabilizacja rozwiązań wyborczych w Polsce sprzyjała utrwalaniu określonych strategii przez rywalizujące podmioty polityczne oraz wyborców, utrudniała wejście na scenę polityczną nowym partiom, zmniejszała poziom fragmentaryzacji na arenie parlamentarnej. Tym samym tzw. rywalizacja otwarta (w której konsekwencje wyborów były dość trudne do przewidzenia) stawała się w coraz większym stopniu tzw. rywalizacją zamkniętą i przewidywalną.

$\mathrm{Na}$ Ukrainie czynnikami kreowania układów rządzących były zarówno wyniki wyborów, jak i mechanizmy pozawyborcze, a w ich ramach współgrające z uwarunkowaniami zewnętrznymi niekonwencjonalne zachowania polityczne na arenie krajowej (bunt, obywatelskie nieposłuszeństwo, kolorowe rewolucje), które przybierały postać tzw. pomarańczowej rewolucji w 2004 roku czy też rewolucji Euromajdanu 10 lat później ${ }^{32}$. Wydarzenia te zmieniały kierunek ewolucji ukraińskiego systemu politycznego, zapobiegając dominacji sceny politycznej przez jeden ośrodek polityczno-biznesowy. Podważały one jednak uzyskiwaną później legitymację wyborczą beneficjentów tych zmian politycznych, tworząc wrażenie, że wyniki wyborów mogą być podważane w imię tzw. racji wyższych.

Infrastruktura prawna elekcji parlamentarnych (czyli systemy wyborcze) charakteryzowała się na Ukrainie również brakiem stabilności. Występowała dość wysoka częstotliwość zmian typów systemów wyborczych, jak również rozwiązań szczegółowych w ich ramach. Do 1998 roku stosowano system większościowy w różnych wariantach. Następnie do roku 2004 wykorzystywano analogiczny do rozwiązań rosyjskich mieszany system wyborczy w wariancie paralelnym, zawierający niezależne od siebie segmenty większościowy i proporcjonalny. W kolejnych dwóch elekcjach do Rady Najwyższej, w okresie po tzw. pomarańczowej rewolucji stosowano typowy dla demokracji parlamentarnych sys-

31 Zob. szerzej: W. Sokól, Geneza i ewolucja systemów wyborczych w państwach Europy Środkowej i Wschodniej, Lublin 1997, s. 274-282.

32 Zob. szerzej: V. Avioutskii, Aksamitne rewolucje, Warszawa 2007, s. 63-130. 
tem proporcjonalny. W 2011 r. sięgnięto po znany już wcześniej system mieszany. Warto zauważyć, że o ile system proporcjonalny (wbrew stereotypowym poglądom) wpływał na zmniejszenie liczby partii politycznych $w$ parlamencie ${ }^{33}$, o tyle system mieszany dawał efekt przeciwny. Wybory przeprowadzane na podstawie systemu mieszanego potwierdziły znane już z wcześniejszych elekcji ukraińskich efekty, m.in. większą fragmentaryzację sceny politycznej w segmencie większościowym (wybór deputowanych w jednomandatowych okręgach wyborczych z mniejszych partii politycznych oraz tzw. kandydatów bezpartyjnych), oligarchizację polityki (dominacja najbogatszych kandydatów w jednomandatowych okręgach wyborczych), regionalizację (podział kraju na strefy wpływów dużych partii politycznych), tendencje do manipulacji granicami okręgów wyborczych (gerrymanderingu) i manipulacji liczbą głosów nieważnych ${ }^{34}$.

Instrumentalne, zwykle zbieżne $\mathrm{z}$ bieżącym zapotrzebowaniem politycznym podejście do polityki reform wyborczych (w Polsce do roku 2002, na Ukrainie permanentnie) nie służyło stabilizacji rozwiązań wyborczych. Sytuacja taka podważała tym samym legitymację wyborczą rządzących. Tworzyła wrażenie, że inżynieria wyborcza przysłania inne demokratyczne funkcje wyborów $w^{35}$.

\section{Specyfika partii politycznych i systemów partyjnych w Polsce i na Ukrainie}

Fundamentalne znaczenie dla demokracji przedstawicielskiej ma zasada pluralizmu politycznego. Pluralizm polityczny zakłada, że każde społeczeństwo jest zróżnicowane pod względem materialnym, kulturowo-światopoglądowym i politycznym, a rywalizacja między ideami, grupami, partiami i jednostkami stanowi najważniejszy mechanizm funkcjonowania demokracji przedstawicielskiej. Demokratyczne państwo prawne jest zobowiązane tworzyć takie rozwiązania instytucjonalne i proceduralne, aby te zróżnicowania mogły znaleźć odzwierciedlenie w sferze realnej polityki państwa.

W pierwszym okresie transformacji systemowej partie polityczne w Polsce powstawały na podstawie linii sporu politycznego wyznaczonego przez orientację postsolidarnościową i postkomunistyczną, istotny wpływ na powstawanie i instytucjonalizację nowych podmiotów miały także kwestie ideowo-programowe, tradycje historyczne, podziały socjoekonomiczne ${ }^{36}$. Później tzw. podział postkomunistyczny ustąpił miejsca na rzecz nowych podziałów (np. tzw. podziałowi postsolidarnościowemu czy postsmoleńskiemu), których wyznacznikiem jest zdominowanie sceny politycznej od kilkunastu lat przez Platformę Obywatelską oraz Prawo i Sprawiedliwośćc ${ }^{37}$.

${ }^{33}$ Zob. szerzej: W. Sokół, op. cit., s. 513.

34 Zob. szerzej: B. Michalak, Mieszane systemy wyborcze. Cele. Rozwiązania. Konsekwencje, Toruń 2013, s. 270 .

35 Zob. szerzej: W. Wojtasik, Funkcje wyborów w III Rzeczypospolitej, Katowice 2012, s. 45-49.

36 Zob. szerzej: W. Sokół, Partie polityczne i system partyjny w III Rzeczypospolitej - elementy ciągłości i zmian, [w:] Demokracja w Polsce po 2015 r., red. D. Plecka, Toruń 2018, s. 35-37.

37 M. Grabowska, Podział postkomunistyczny. Społeczne podstawy polityki w Polsce po 1989 roku, Warszawa 2004, s. 228-231; J. Sielski, Czynniki zmian polskiego systemu partyjnego po 1989 r., [w:] Partie i system partyjny RP, stan i perspektywy, red. K. Kowalczyk, Ł. Tomczak, Toruń 2007, s. 51. 
O ile jeszcze na przełomie 1989/1990 brakowało typowej dla demokracji parlamentarnej sceny partyjnej, co skutkowało licznymi patologiami transformacji społeczno-gospodarczej ${ }^{38}$, o tyle już od pierwszych wolnych wyborów parlamentarnych w 1991 roku występował wysoki poziom fragmentaryzacji sceny politycznej i zmienność formuł organizacyjnych partii politycznych. Politycy często porzucali skompromitowane podmioty, tworząc kolejne oferty dla wyborców. Zarówno system wyborczy, system finansowania polityki, jak i podziały socjopolityczne i związana z tym krystalizacja zachowań wyborczych przyczyniły się do stabilizacji sceny partyjnej ${ }^{39}$. Współczesne relewantne partie funkcjonują od 2001 roku w niezmienionej formule organizacyjnej, a niektóre jeszcze dłużej. Są to nowoczesne ugrupowania profesjonalno-wyborcze, aktywne nie tylko w okresie kampanii wyborczych, nastawione na długofalowe strategie, rozliczane z realizacji swoich obietnic wyborczych, innowacyjne w zakresie komunikacji z wyborcami. W tym względnie ustabilizowanym systemie partyjnym w XXI wieku pojawiają się partie nowe, które z trudem próbują uzyskać status równorzędnych uczestników rywalizacji politycznej ${ }^{40}$.

Temperatura sporów politycznych w Polsce jest wysoka. Niezależnie od krajowych i zagranicznych narracji politycznych eksponujących m.in. zagrożenia dla demokracji i praworządności nie są jednak podważane przez uczestników rywalizacji politycznej wartości i zasady funkcjonującego systemu ${ }^{41}$.

Charakteryzując system partyjny Ukrainy, należy zwrócić uwagę na inne niż w Polsce podziały socjopolityczne (m.in. na tle narodowościowym, regionalnym, tradycji historycznych, orientacji w polityce zagranicznej, postsowieckiej mentalności) w społeczeństwie tego państwa ${ }^{42}$. Wspomniane podziały socjopolityczne kształtowały orientacje polityczne (np. podział na obóz pomarańczowy vs obóz błękitnoniebieski) zbliżone do układów dwubiegunowych. W drugiej dekadzie obecnego wieku w dalszym ciągu zwraca uwagę duża liczba partii politycznych na arenie parlamentarnej i wyborczej, podobnie jak w Polsce w początkach lat 90. XX wieku.

Początkowo, po ogłoszeniu niepodległości na ukraińskiej scenie politycznej występowała tendencja do powstawania ugrupowań identyfikowanych przynależnością do określonego nurtu ideologicznego. Z czasem zaczęły dominować tzw. partie inte-

38 Istniało wówczas ryzyko powstania jednej „etosowej” partii politycznej, której linia byłaby wyznaczana przez autorytety. Zob. szerzej: J. Kaczyński, Porozumienie przeciw monowładzy. Z dziejów PC, Poznań 2016, s. 99.

39 Szczególnie przepisy dotyczące finansowania partii politycznych z budżetu państwa pozwoliły na wyeliminowanie wielu patologii dotyczących finansowania polityki, obecnych jeszcze w polskim życiu politycznym w latach 90 . XX wieku.

40 Zob. szerzej: W. Sokół, Zmiany w systemie partyjnym III Rzeczypospolitej, [w:] Demokracja w Polsce po 2007 roku, red. D. Plecka, Katowice 2014, s. 63-92.

${ }_{41}$ J. Sielski, op. cit., s. 51.

42 Zob. szerzej: W. Baluk, op. cit., s. 157, passim. 
resu $^{43}$. Decydujący był wpływ układów biznesowo-politycznych na powstawanie partii politycznych, potrzebujących swojej reprezentacji politycznej. Zatem partie w Ukrainie to w znaczącym stopniu podmioty polityczne tworzone często na użytek jednych wyborów i realizujące interesy polityczno-ekonomiczne tzw. oligarchów i powiązanych z nimi układów klientystycznych. Powstawaniu partii kreowanych przez układy biznesowo-polityczne sprzyjał system finansowania partii politycznych (możliwość finansowania przez podmioty prawne i fizyczne ${ }^{44}$ ) oraz brak nadzoru i transparentności w zakresie finansowania polityki ukraińskiej. Należy jednak zauważyć, że przyjęta w $2015 \mathrm{r}$. ustawa o partiach wprowadzająca finansowanie z budżetu państwa zwiększa szanse na równe warunki rywalizacji wyborczej.

Wspólną cechą polskich i ukraińskich partii politycznych jest występowanie w jednych i drugich spersonalizowanego przywództwa partyjnego, chociaż dodatkowo na Ukrainie wiąże się ono z procesami oligarchizacji życia politycznego. $Z$ dotychczasowej praktyki politycznej wynika, że stronnictwa ukraińskie najczęściej były tworzone na użytek kolejnych wyborów. Czas funkcjonowania na arenie politycznej partii ukraińskich jest zdecydowanie krótszy niż w Polsce. Przyczyną tego faktu jest ich słaba instytucjonalizacja oraz niezbyt poważne traktowanie składanych w kampaniach wyborczych (nierealnych na ogół) obietnic, co jednak skutkuje niskim poziomem lojalności wyborczej (tym samym wyjątkowo wysokim poziomem tzw. chwiejności wyborczej) i tworzeniem nowych podmiotów przed zbliżającymi się kolejnymi wyborami. W trakcie kolejnych kadencji Rady Najwyższej następował gwałtowny spadek poparcia dla relewantnych partii parlamentarnych.

Nawiązując do tezy wyjściowej artykułu, należy zauważyć, że instytucje i procedury demokratyczne kształtujące się w Polsce w okresie transformacji i konsolidacji demokracji, chociaż wykazywały wiele ułomności (m.in. partyjniactwo, niska aktywność wyborcza, niesprawna administracja, niewydolne sądownictwo ${ }^{45}$ ), w porównaniu do państw Europy Wschodniej skutecznie zakorzeniły się w polskim życiu politycznym, sprzyjając rozwojowi cywilizacyjnemu i jednocześnie wykazując odporność na

43 Pomimo że następował stopniowy zanik partii politycznych odwołujących się do tradycyjnych ideologii (np. zwraca uwagę erozja partii socjaldemokratycznej), to powyższy proces nie dotyczył partii nurtu nacjonalistycznego. Renesans ideologii nacjonalistycznej na Ukrainie sprawił, że partie narodowe, chociaż są dość słabe na arenie wyborczej, wpływają skutecznie na strategie relewantnych podmiotów w życiu politycznym Ukrainy. Zob. szerzej: T.A. Olszański, Partia Swoboda - nowa jakość na ukraińskiej prawicy, Ośrodek Studiów Wschodnich 2011, http://www.osw.waw.pl, s. 2 [dostęp: 27.09.2017].

44 „Obecna sytuacja sprzyja nadużyciom i zasilaniu kont partyjnych nawet przez podstawione osoby. Nowa ustawa, która wejdzie jednak w życie dopiero za dwa lata, ma to zmienić i ucywilizować cały proces" -powiedział Polskiej Agencji Prasowej Witalij Tesłenko z Komitetu Wyborców Ukrainy, organizacji, która zajmuje się monitorowaniem wyborów w kraju, https://wiadomosci.onet.pl/ swiat/ukraina-porzadkuje-niejasne-dotad-zasady-finansowania-partii-politycznych/jk9kr3 [dostęp: 17.04.2018].

45 Zob. szerzej: Raport PiS o stanie państwa, www.newsweek.pl/polska/raport-o-stanie-rzeczypospolitej. artykuly.74598,1,1,1.html [dostęp: 18.04.2018]. 
zagrożenia populistyczne lub oligarchiczne. Na tym tle dynamika zmian ustrojowych w Ukrainie była dość wysoka. System polityczny charakteryzował się brakiem stabilizacji. Instytucje polityczne nie funkcjonowały prawidłowo i nie sprzyjały integracji oraz modernizacji społecznej. Brakowało rozwiązań właściwych dla tworzenia demokracji konsensualnej. Problemem był brak poszanowania dla procedur prawnych zarówno ze strony władzy, jak i obywateli. Samo ustanowienie określonych rozwiązań instytucjonalnych nie zapewnia trwałości reżimu demokratycznego. Tym samym należy podkreślić, że instytucje i rozwiązania znane z polskiego systemu politycznego mogą być zinternalizowane przez Ukrainę pod warunkiem m.in. zmian w sferze kultury politycznej, poszanowania dla zasad państwa prawa ( $w$ tym $m$.in. istotnego ograniczenia korupcji), wzmocnienia infrastruktury i aktywności społeczeństwa obywatelskiego, uzyskania przez system polityczny cech transparentności i dojrzałości.

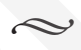

Streszczenie: Celem artykułu będzie porównanie niektórych elementów systemów politycznych Rzeczypospolitej Polskiej i Ukrainy zarówno w ujęciu strukturalnym, jak i funkcjonalnym. Przedmiotem opracowania będzie geneza i kierunki zmian ustrojowych, specyfika systemów rządów, mechanizmy rywalizacji politycznej oraz jej główni aktorzy, czyli partie polityczne. Z analizy wynika, że rozwiązania ustrojowe w Polsce charakteryzowały się większą stabilnością, przywiązaniem do zasad państwa prawnego i wartości demokratycznych. W ustroju politycznym Ukrainy występowała dość duża dynamika zmian w tym zakresie. Powyższe zmiany w większym stopniu niż w Polsce miały charakter instrumentalny, podporządkowany preferencjom dominujących w poszczególnych okresach sił politycznych. Słowa kluczowe: Ukraina, Polska, demokratyzacja, system polityczny, system rządów, rywalizacja polityczna, system wyborczy, partie polityczne

\section{Directions and political effects of changes in the political systems of Poland and Ukraine}

Abstract: The aim of the study will be to compare some elements of the political systems of the Republic of Poland and Ukraine in both structural and functional terms. The subject of the study will be the genesis and directions of systemic changes, the specificity of government systems, mechanisms of political rivalry and its main actors, that is, political parties. The analysis shows that systemic solutions in Poland were characterized by greater stability, attachment to the principles of the rule of law and democratic values. In the political system of Ukraine there was quite a large dynamics of changes in this area. These changes were instrumental in a greater degree than in Poland, subordinated to preferences dominating in particular periods of political forces.

Keywords: Ukraine, Poland, democratization, political system, system of government, political competition, electoral system, political parties 
Pobrane z czasopisma Wschód Europy http://journals.umcs.pl/we

Data: 26/04/2023 12:32:58

\section{Направления и политические последствия изменений в политических системах Польши и Украины}

Аннотация: Целью исследования будет сравнение некоторых элементов политических систем Республики Польши и Украины как в структурном, так и в функциональном отношении. Предметом исследования станут генезис и направления системных изменений, специфика государственных систем, механизмы политического соперничества и его основные действующие лица, то есть политические партии. Анализ показывает, что системные решения в Польше характеризовались большей стабильностью, приверженностью принципам верховенства закона и демократическим ценностям. В политической системе Украины произошли довольно динамичные изменения в этой сфере. Эти изменения сыграли важную роль в большей степени, чем в Польше, в зависимости от предпочтений политических сил, доминирующих в определенные периоды.

Ключевые слова: Украина, Польша, демократизация, политическая система, система правления, политическая конкуренция, избирательная система, политические партии

\section{Bibliografia}

A Report from the Economist Intelligence Unit, http://www.eiu.com/home.aspx\#offer-ss-data [dostęp: 27.05.2017].

Avioutskii V., Aksamitne rewolucje, Warszawa 2007, s. 63-130.

Baluk W., Kształtowanie systemu partyjnego Ukrainy w okresie transformacji ustrojowej (1987-2004), Wrocław 2006, s. 171-178.

Będzie spór między Andrzejem Dudą a PiS. Partia chce ograniczenia władzy prezydenta, http://wiadomosci.gazeta.pl/wiadomosci/7,114884,23278047,bedzie-spor-miedzy-andrzejem-duda-a-pis-partia-chce-ograniczenia.html [dostęp: 16.04.2018].

Carothers T., The End of the Transition Paradigm, „Journal of Democracy” 2002, nr 13, s. 5-21.

DOl: https://doi.org/10.1353/jod.2002.0003

Chodakiewicz J. M., Międzymorze, Warszawa 2016, s. 254-255.

Donaj Ł., Współczesny kryzys społeczno-polityczny na Ukrainie jako przykład cykliczności (chroniczności?) procesów politycznych, „Środkowoeuropejskie Studia Polityczne” 2012, nr 3, s. 204-206.

Dudek A., Historia polityczna Polski 1989-2015, Kraków 2016, s. 17-140.

Fedorowicz K., "Pomarańczowa rewolucja” na Ukrainie - czas realizacji wyborczych deklaracji, [w: „Pomarańczowa rewolucja" - szansa dla ukraińskiej transformacji politycznej, red. A. Furier, Szczecin 2006, s. 129-147.

Fedorowicz K., Transformacja systemowa na Ukrainie - etap przejściowy czy nowy model państwa, [w:] Od totalitaryzmu do demokracji. Wybrane problemy okresu przemian, red. T. Wallas, Poznań 2003, s. $43-55$.

Fedorowicz K., Ukraińskie rewolucje a parlamentaryzm, „Rocznik Instytutu Europy Środkowo-Wschodniej" 2014, z. 2, s. 57-74.

Grabowska M., Podział postkomunistyczny. Społeczne podstawy polityki w Polsce po 1989 roku, Warszawa 2004, s. 228-231. 
Pobrane z czasopisma Wschód Europy http://journals.umcs.pl/we

Data: 26/04/2023 12:32:58

Kierunki i efekty polityczne zmian w systemach politycznych Polski i Ukrainy

Grześkowiak A., Ustrój polityczny III Rzeczypospolitej według projektu konstytucji senackiej komisji konstytucyjnej, „Roczniki Nauk Prawnych”, Toruń 1991-1992, s. 99-106.

Hurska-Kowalczyk L., Ewolucja form rządów na Ukrainie, [w:] Dylematy rozwoju Ukrainy, red. L. Hurska-Kowalczyk, Szczecin 2011, s. 35.

Kaczyński J., Porozumienie przeciw monowładzy. Z dziejów PC, Poznań 2016, s. 99.

Kasjanow G., Ukraina 1997-2007. Narisi nowimnoj istorii, Kijów 2008, s. 62-63.

Konstytucja Rzeczypospolitej Polskiej, oprac. D. Dudek, Lublin 2007, s. 93.

Konstytucja Ukrainy, Warszawa, s. 86.

Michalak B., Mieszane systemy wyborcze. Cele. Rozwiązania. Konsekwencje, Toruń 2013, s. 270.

Mojak R., Pozycja ustrojowa Prezydenta RP w świetle nowej Konstytucji RP, „Państwo i Prawo” 1997, nr 11-12, s. 54-70.

Nations in Transit 2006, http: www.freedomhouse.hu/index.php?option=com_content\&task=view\&id=47 [dostęp: 16.04.2018].

Olechno A., Instytucja Prezydenta w systemie konstytucyjnych organów Ukrainy (1996-2005), Toruń 2009.

Olszański T.A., Partia Swoboda - nowa jakość na ukraińskiej prawicy, Ośrodek Studiów Wschodnich, 2011; http://www.osw.waw.pl, s. 2 [dostęp: 27 IX 2017]

Olszański T.A., Sąd Konstytucyjny przywraca system prezydencki na Ukrainie, Ośrodek Studiów Wschodnich 2010, http://www.osw.waw.pl, s. 2 [dostęp: 27.09.2017].

Prezydent w Polsce po 1989 r. Studium politologiczne, red. R. Glajcar, M. Migalski, Warszawa 2006, passim.

Projekt Prawa i Sprawiedliwości. Konstytucja Rzeczypospolitej Polskiej, styczeń 2010, http://niezniknelo. com/konstytucjaPiS [dostęp: 16.04.2018].

Rakowska A., Skotnicki K., Konstytucja RP na tle innych obowiązujących Ustaw zasadniczych państw Europy Środkowo-Wschodniej i Południowej, „Przegląd Sejmowy” 2007, nr 4, s. 215-216.

Raport PiS o stanie państwa, www.newsweek.pl/polska/raport-o-stanie-rzeczypospolitej.artykuly.74598,1,1,1.html [dostęp: 18.04.2018].

Sielski J., Czynniki zmian polskiego systemu partyjnego po 1989 r., [w:] Partie i system partyjny RP, stan i perspektywy, red. K. Kowalczyk, Ł. Tomczak, Toruń 2007, s. 51.

Sokół W., Geneza i ewolucja systemów wyborczych w państwach Europy Środkowej i Wschodniej, Lublin 1997, s. 274-282.

Sokół W., Partie na arenie parlamentarnej i gabinetowej, [w:] Współczesne partie i systemy partyjne. Zagadnienia teorii i praktyki politycznej, red. W. Sokół, M. Żmigrodzki, Lublin 2003, s. 182-197.

Sokół W., Partie polityczne i system partyjny w III Rzeczypospolitej - elementy ciągłości i zmian, [w:] Demokracja w Polsce po 2015 r., red. D. Plecka, Toruń 2018, s. 35-37.

Sokół W., Zmiany w systemie partyjnym III Rzeczypospolitej, [w:] Demokracja w Polsce po 2007 roku, red. D. Plecka, Katowice 2014, s. 63-92.

Stawicki R., Zmiany Konstytucji Rzeczypospolitej Polskiej w latach 1997-2011 w świetle projektów ustaw oraz uchwalonych nowelizacji, Warszawa 2011, passim.

Stelmach A., Legalność zmiany władzy na Ukrainie, „Środkowoeuropejskie Studia Polityczne” 2015, vol. 4, s. 16-17.

Szymanek J., Zabezpieczenia konstytucji przed zmianą konstytucji, „Prawo i Polityka” 2015, nr 6, s. 15. 
Pobrane z czasopisma Wschód Europy http://journals.umcs.pl/we

Data: 26/04/2023 12:32:58

Ukraina porządkuje niejasne zasady finansowania partii politycznych, https://wiadomosci.onet.pl/swiat/ukraina-porzadkuje-niejasne-dotad-zasady-finansowania-partii-politycznych/jk9kr3 [dostęp: 17.04.2018]. Wojtasik W., Funkcje wyborów w III Rzeczypospolitej, Katowice 2012, s. 45-49.

Zakon Ukrajiny pro widnowlennia diji okremych polożen' Konstytuciji Ukrajiny wid 21 || 2014, „Widomosti Werhownoi Radi" 2014, nr 11, poz. 143.

Zakon Ukrajiny pro zminy do Konstytuciji Ukrajiny (szczodo pravosuddia), http://zakon5.rada.gov.ua/ laws/show/1401-VIII

Zieliński E., System konstytucyjny Ukrainy, Warszawa 2007, s. 16-17. 